УДК 378.147:373.3.091.2:004

DOI:

Іван Василиків, кандидат педагогічних наук, старший викладач кафедри математики, інформатики та методики їх викладання у початковій школі, магістр факультету початкової та мистеиької освіти Дрогобицького державного педагогічного університету імені Івана Франка

\title{
ОСОБЛИВОСТІ ЗАСТОСУВАННЯ ІНФОРМАЦІЙНИХ ТЕХНОЛОГІЙ У ПІДГОТОВЦІ МАЙБУТНІХ УЧИТЕЛІВ ПОЧАТКОВОЇ ШКОЛИ
}

У статті окреслено перспективи впровадження хмарних технологій у навчальний прочес підготовки вчителів початкової школи. Виділено основні переваги хмарних технологій в проиесі професійної підготовки майбутніх фахівців початкової школи. Дистанційне навчання із застосуванням хмарних технологій полягає у тому, що студенти дистанційно навчаються приймаючи участь у вебінарах, майстер-класах, спілкуються з іншими суб 'єктами освітнього простору, завдяки чому відбувається швидкий обмін досвідом, стимулюється самоосвіта і самовдосконалення.

Ключові слова: хмарні технологї̈; вчителі початкової школи; ПК; Microsoft Office 365; Google G Suite; IT; Інтернет.

Jim. 10.

Ivan Vasylykiv, Ph.D.(Pedagogy), Senior Lecturer of the Mathematics, Informatics and Methods of Teaching in Elementary School Department, Master Student of the faculty of Elementary and Artistic Education Drohobych Ivan Franko State Pedagogical University

\section{THE FEATURES OF USING THE INFORMATION TECHNOLOGIES IN THE PROCESS OF TRAINING OF FUTURE TEACHERS OF PRIMARY SCHOOL}

The article deals with the perspectives of introduction of cloud technologies into the educational process of preparation of teachers of elementary school. The main advantages of cloud technologies in the process of professional training of future primary school specialists are highlighted: an access to all necessary programs via the Internet; saving on the purchase, maintenance, upgrading of software and equipment; remote access to data in the cloud; no significant computing power of a PC; high security and data processing speed; the memory of the device used to access the cloud is not populated - all data is stored online. The comparative analysis of traditional and cloud technologies is carried out. The practical application of cloud technologies is carried out according to the scheme of distance learning through the common work of students, common project work, distance learning. To work together with cloud-based technologies, it must be created or placed a document in a cloud-based repository and provided access to it. In assessing the student's project activity, the teacher can track the chronology of changes and determine the contribution made by each member of the group. Distance learning with the use of cloud technologies is that students learn distance learning through webinars, workshops, communicate with other students in the educational space, which results in the rapid exchange of experience stimulated the self-education and selfimprovement.

Keywords: cloud technologies; the teachers of elementary school; PC; Microsoft Office 365; Google G Suite; IT Internet.

П

остановка проблеми. Особливості переходу від індустріального до інформаційного суспільства сприяє скороченню життєвого циклу знань і навичок, перетворюючи функцію освіти 3 разової в регулярну, для якої властиве постійне оновлення професійних знань і вмінь 3 урахуванням швидкозмінних процесів у розвитку цивілізації $\mathrm{i}$ суспільства. У таких умовах традиційна форма денного навчання становиться лише частиною загального освітнього процесу, а безперервно зростає доля участі в освітньому процесі інформаційних технологій - в першу чергу, персонального комп'ютера, мережі Інтернет і телекомунікацій.

Інформаційне суспільство ставить підвищенні вимоги до професійної підготовки майбутніх учителів початкової школи, яка повинна передбачати умови швидкозмінного суспільства і темпи розвитку цивілізації.

Аналіз останніх досліджень і публікацій. Аналіз літературних джерел показав, що різні аспекти використання IT у навчальному процесі закладів вищої освіти відображені в роботах В. Волинського [6], Р. Гуревича [4; 5], А. Гуржія [6], М. Жалдака, Г. Козлакової, М. Коула, 


\section{ОСОБЛИВОСТІЗАСТОСУВАННЯІНФОРМАЦЙНИХ ТЕХНОЛОГЙ \\ У ПДГОТОВЦІ МАЙБУТНІХ УЧИТЕЛІВ ПОЧАТКОВОӤ ШКОЛИ}

А. Кузнєцова, Ю. Машбиця, В. Монахова,

В. Новикова.

Мета статті. На жаль, сьогодні педагогічна освіта не має засобів для залучення багатомільйонної аудиторії у інформаційне середовище для отримання професійного знання, тому важливою проблемою є ретельний відбір таких засобів інформаційних технологій у підготовці майбутніх учителів початкової школи, які б могли сприяти їі удосконаленню в умовах бюджетного дефіциту.

Виклад основного матеріалу. Протягом всього процесу підготовки майбутніх учителів початкової школи доцільно застосовувати загальнодоступні хмарні платформи Google Suite та Microsoft Office 365. Ïx розроблювачі висувають безплатні підписки для освітніх закладів. Як результат студенти та викладачі одержують корпоративні облікові записи цих хмарних платформ. Навчання застосовуванню даних платформ дозволено втілювати у границях звичних предметів низки професійної підготовки майбутнього учителя початкової школи, наприклад: операційні системи, комп'ютерні мережі, основи Інтернет.

Значний педагогічний потенціал вбачаємо у використанні корпоративних хмарних платформ, які дають змогу організувати “віртуальні хмарні лабораторії” [8]. Розглядаючи процес підготовки майбутнього вчителя початкової школи, під віртуальною лабораторію розумітимемо інформаційну систему, в якій завдяки спеціальному інтерфейсу користувача, що підтримується системними програмними засобами мережного налаштування, формуються мережні віртуальні IT-об'єкти. На нашу думку, віртуальні хмарні лабораторії найбільш доцільно використовувати у процесі навчання мережних технологій та програмування.

Розгорнуту лабораторію було використано як засіб навчання у процесі проведення комп'ютерної практики. Ії̈ метою було формування професійних умінь та навичок, виховання потреби систематичного поповнення знань, вмінь творчо застосовувати їх через проектну діяльність. Для виконання зазначених завдань студенти повинні засвоїти зміст курсів “Операційні системи”, “Програмне забезпечення комп'ютерних систем”, “Архітектура комп'ютерів”.

Проекти стосувалися розв'язання практично значимих задач, зокрема:

- відновлення знищених даних;

- підвищення швидкодії операційних систем;

- виправлення помилок при їх завантаженні;

- знешкодження вірусів.
Перед початком розв'язання практичних задач студентам було запропоновано опрацювати відповідний теоретичний матеріал. Співпрацю та спільну діяльність забезпечувало застосування загальнодоступних хмар G Suite та Microsoft Offlice 365, використовуючи які студенти виконували:

- обговорення навчальних проблем у межах відкритих та приватних груп;

- планування та координування спільної діяльності;

- створення та редагування спільних матеріалів (схема, реферат, брошура, буклет, інфографіка);

- надання доступу до файлів;

- публікування відеороликів, які демонструють процес вирішення проблем;

- рефлексію.

Для роботи над проектами було використано груповий метод. Завдяки цьому студенти набувають навичок спільної роботи - спілкування, роботи у складі та на чолі групи; формулювання завдань для себе та колег, виконувати задач у визначений термін [1]

Кожному 3 учасників групи було надано окремий віртуальний комп'ютер, операційна система якого мала вади одного з вищенаведених типів. Для забезпечення повсюдного доступу до обчислювальних потужностей віртуальної лабораторії було організовано сервер віртуальних приватних мереж. Отож, студенти змогли працювати на розв'язанням задач не лише з будьякого комп'ютера університету, а й з домашнього ПК. Крім цього використання засобів хмарних технологій забезпечило оперативний зворотній зв'язок, зокрема завдяки оперативному контролю та допомозі викладача.

Застосування хмарних технологій як об'єкта вивчення ми пропонуємо здійснювати у формі спецкурсу “Основи хмарних технологій”. Його основним завданням вважаємо формування компетентностей, необхідних для самостійного розгортання хмарних платформ на основі комерційних та відкритих програмних засобів. Підготовка до застосування хмарних технологій у майбутній професійній діяльності передбачає вивчення: загальнодоступних хмарних платформ визнаних вендорів у галузі розробки програмного забезпечення та відкритих програмних засобів як основи корпоративних хмар.

Вивчення загальнодоступних платформ G Suite та Microsoft Office 365 пропонуємо здійснювати у формі проекту “Хмарні сервіси у кожну школу".

Його завдання полягають у проектуванні та розгортанні хмарних сервісів для загальноосвітніх, 


\section{ОСОБЛИВОСТІ ЗАСТОСУВАННЯІНФОРМАЦЙНИХ ТЕХНОЛОГИЙ У ПЦДГОТОВЦ МАЙБУТНІХ УЧИТЕЛІВ ПОЧАТКОВОЇ ШКОЛИ}

які долучилися до проекту. Базовими засадами у концепції проекту вважаємо такі:

- відсутність будь-якого серверного обладнання ушколі, яке необхідне для функціонування хмарних сервісів;

- відсутність або мінімальна величина матеріальних витрат на розгортання супровід хмарних сервісів;

- добровільний характер проекту через залучення ініціативних та вмотивованих учителів.

У співпраці із вчителями початкової школи студенти визначають, які сервіси, як складові середовища, потрібно конфігурувати або мігрувати у хмари. Як свідчить досвід значної уваги потребують проблеми супроводу та підтримки розгорнутих систем. Часто у вчителів виникають питання стосовно адміністрування, конфігурування, моніторингу хмарних сервісів. Вирішення таких проблем ми здійснювали у напрямах організації очних та дистанційних тренінгів, семінарів, практикумів; дистанційного супроводу систем студентами.

Висновки. Вважаємо, що результативність проекту загалом відповідає індикаторам розвитку хмаро-орієнтованого навчального середовища: якістю і доступністю навчання, адаптивністю, інтеграцією, інтерактивністю та мобільністю ITзасобів, уніфікацію інформаційної інфраструктури школи, іiі безпека тощо.

Участь студентів упроекті має такі педагогічні ефекти:

- негайний, який отримуємо завдяки розвитку у студентів інформатичних та інформаційних компетентностей;

- проміжний, що полягає в усвідомленні себе в ролі вчителя, у спрямованості на результат.

- віддалений, який передбачає усвідомлення необхідності та готовності працювати вчителем, формування позитивного образу вчителя, бажання використовувати хмаро-орієнтовані засоби у навчанні.

Перспективи подальших досліджень бачимо у розробці методики навчання студентів щодо розгортання та супроводу корпоративних хмар відповідно до моделі “інфраструктура як сервіс” [7].

\section{ЛІТЕРАТУРА}

1. Балик Н. Р. Формування інформаційних та соціальних компетентностей студентів з метою їх професійної підготовки у педагогічному університеті / Н. Р. Балик, Г. П. Шмигер // Науковий огляд. - 2016. - №1. - С. 1 - 7.

2. Гуревич Р. С. Перспективи освіти в інформаційному суспільстві // Актуальні проблеми виробничих та інформаційних технологій, економіки і фундаментальних наук: 3б. наук, праць. - Вінниця Планер, 2005. - Вип. 2. - 546 с.

3. Гуревич Р. С., Кадемія М. Ю. Інформаційнотелекомунікаційні технології в навчальному процесі та наукових дослідженнях: Навч. посібник для студентів пед. ВНЗ і слухачів ін-тів піспядипломної освіти. - Вінниця: ДОВ “Вінниця”, 2004. - 365 c.

4. Гуржій А. М., Жук Ю. О., Волинський В. П. Засоби навчання: Навч. посібник. - К.: ІЗМН, 1997. - 208 c.

5. Мойсеєнко Л. Д. Про психічну готовність студентів технічного вузу до використання ЕОМ // Педагогіка і психологія. - 1997. - № 2. - С. 156 $-161$.

6. Монсеюк А. С. Педагогіка. Навч. посібник. - 3-є вид., доп. - К.: КДНК, 2001. - 608 с.

7. Олексюк В. П. Застосування віртуальних хмарних лабораторій у процесі підготовки майбутніх учителів інформатики / В. П. Олексюк // Науковий часопис НПУ імені М. П. Драгоманова. Серія 2: Комп'ютерно-орієнтовані системи навчання. - 2015. - №. 15. - С. 76 - 81. - Режим доступу: http://nbuv.gov.ua/UJRN/ Nchnpu 2 2015 $15 \quad 15$

8. Олексюк В. П. Проектування моделі хмарної інфраструктури ВНЗ на основі платформи Apache CloudStack. / В.П. Олексюк // Інформаційні технології і засоби навчання. - 2016. - №4. C. $153-164$.

9. Петришин I. Шляхи підвищення професійного рівня майбутніх учителів трудового навчання засобами сучасних інформаційно-комунікаційних технологій//Молодь і ринок. - 2006. - № 8(23). - С. $65-70$.

10. Рибачук А. В. Вплив комп'ютерних технологій на інтенсифікацію навчання у вищій школі // Сучасні інформаційні технології та інноваційні методики навчання у підготовці фахівців: методологія, теорія, досвід, проблеми: Зб. наук, праць. - Київ-Вінниця: ДОВ “Вінниця”, 2006. - Вип. 10. - С. $442-445$.

\section{REFERENCES}

1. Balyk, N. R. \& Shmyher, H. P. (2016). Formuvannia informatsiinykh ta sotsialnykh kompetentnostei studentiv $\mathrm{z}$ metoiu yikh profesiinoi pidhotovky u pedahohichnomu universyteti [The formation of informational and social competencies of students with the aim of their professional training at the Pedagogical University]. Scientific review. No.1, pp. 1 - 7. [in Ukrainian].

2. Hurevych, R. S. (2005). Perspektyvy osvity v informatsiinomu suspilstvi [Prospects of education in 
the information society]. The actual problems of production and information technologies, economics and fundamental sciences: A collection of scientific works. Vinnytsia Planer, vol. 2, 546 p. [in Ukrainian].

3. Hurevych, R. S. \& Kademiia, M. Yu. (2004). Informatsiino-telekomunikatsiini tekhnolohii $\mathrm{V}$ navchalnomu protsesi ta naukovykh doslidzhenniakh [Information and telecommunication technologies in the educational process and scientific research]. Teaching manual for students of Pedagogical institutions of higher education and for the students of institutes of higher education and diploma education. Vinnytsia: DOV "Vinnytsia", 365 p. [in Ukrainian].

4. Hurzhii, A. M., Zhuk, Yu. O. \& Volynskyi, V. P. (1997). Zasoby navchannia [Learning Tools]. Tutorial. Kyiv: IZMN, 208 p. [in Ukrainian].

5. Moiseienko, L. D. (1997). Pro psykhichnu hotovnist studentiv tekhnichnoho vuzu do vykorystannia EOM [About the psychological readiness of students of the technical college to the usage of the Electronic Computing Machine]. Pedagogy and Psychology. No. 2, pp.156 - 161. [in Ukrainian].

6. Monseiuk, A. Ye. (2001). Pedahohika. Navch. posibnyk [Pedagogy]. Teaching manual the 3rd edition, Additional. Kyiv: KDNK, 608 p. [in Ukrainian].

7. Oleksiuk, V. P. (2015). Zastosuvannia virtualnykh khmarnykh laboratorii u protsesi pidhotovky maibutnikh uchyteliv informatyky
[Application of Virtual Cloud Laboratories in the Process of Preparing of Future Teachers of Informatics]. Scientific journal of the National Mykhaylo Drahomanov Pedagogical University. Series 2: the Computer-based learning systems. No. 15, pp. $76-81$. Available at: http://nbuv.gov.ua/ UJRN/Nchnpu_2_2015_15_15

8. Oleksiuk, V. P. (2016). Proektuvannia modeli khmarnoi infrastruktury VNZ na osnovi platformy Apache CloudStack [The design of Cloud Computing Infrastructure Models Based on Apache CloudStack Platform]. The information technologies and teaching aids. No.4, pp.153 - 164. [in Ukrainian].

9. Petryshyn, I. (2006). Shliakhy pidvyshchennia profesiinoho rivnia maibutnikh uchyteliv trudovoho navchannia zasobamy suchasnykh informatsiinokomunikatsiinykh tekhnolohii [The ways of improving the professional level of future teachers of labor education by means of modern information and communication technologies].Youth and market. Monthly scientific-pedagogical journal, vol. 8 (23), pp. 65 - 70. [in Ukrainian].

10. Rybachuk, A. V. (2006). Vplyv kompiuternykh tekhnolohii na intensyfikatsiiu navchannia u vyshchii shkoli [Influence of computer technologies on intensification of studies in the high school]. The modern information technologies and innovative methods of training in the training of specialists: the methodology, theory, experience, problems: A collection of scientific works. Kyiv-Vinnytsia: DOV "Vinnytsia", vol.10, pp. 442 - 445. [in Ukrainian].

Стаття надійшла до редакції 04.09.2018

\section{GS808DC2}

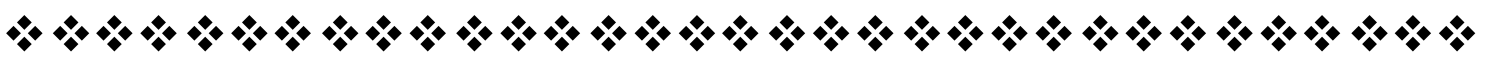

"Розуміти щось - значить знайти в ньому щось тақе, що є наше; $i$ яқраз оце відкриття себе поза нами є тим, що нас тішить".

Рабіндранат Tाагор

бенгальський та індійський писъменник

"Коли руйнується план, немає қращої розради, як на його місиі побудувати новий або мати в запасі інший”.

Жан $\overparen{T} о л ь$

браниузъкий актор

"Виіться так, немов ви постійно відчуваєте нестачу своїх знань, $і$ так, немов ви постійно побоюєтеся розгубити свої знання".

Конбучій

давнъокитайсъкий білособ

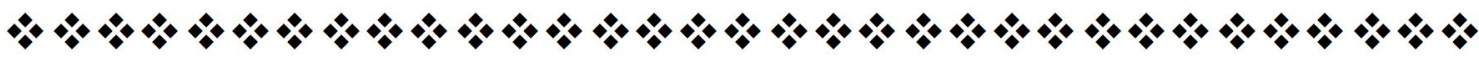

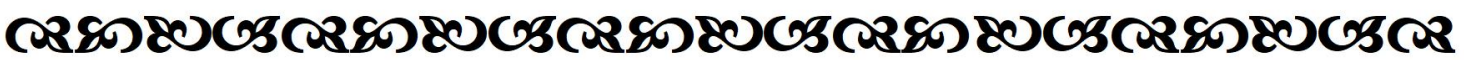

